\title{
Treatment of Textile Dyes by Bio-chemical Process in Stirred Tank Sequencing Batch Bioreactor (STSBBR)
}

\author{
Pradip saha $^{1}$, M. R. Khan*1, ${ }^{1,}$ T. K. Deb ${ }^{3}$, S. Y. Sony ${ }^{3}$, A. C. Baishnab ${ }^{3}$ \\ ${ }^{1}$ Faculty of Chemical Engineering and Polymer Science, Shahjalal University of Science and Technology (SUST), \\ Sylhet 3114, Bangladesh. E-mail: pradip-cep@sust.edu \\ ${ }^{2}$ Faculty of Chemical and Natural Resources Engineering, University Malaysia Pahang, 26300 Gambang, Kuantan, \\ Pahang, Malaysia \\ ${ }^{3}$ Research student, Department of Chemical Engineering and Polymer Science, Shahjalal University of Science and \\ Technology (SUST), Sylhet 3114, Bangladesh.
}

\begin{abstract}
A bacterial isolate Pseudomonas sp. was isolated from the solid waste slump collected from a local duping site of Sylhet district and was efficiently utilized for the removal of dye (Orange 3R) from simulated synthetic waste water in a lab scale Stirred Tank Sequencing Batch Bioreactor (STSBBR) in batch mode. A reactor with 2 L capacity (working volume $0.5 \mathrm{~L}$ ) equipped with suitable control means and stirring mechanism was operated at room temperature and $\mathrm{pH}$ $\mathbf{6 . 6} \pm \mathbf{1}$ in fill-react-settling-draw mode with different initial dye concentrations $(50,100,150,200 \& 300 \mathrm{ppm})$ where the hydraulic retention time was maintained for 12-72 hours depending on the adaptation of waste water by the bacterial strain. The efficiency of the reactor was analyzed with respect to three strands and found to be negative correlation with the concentration of the dye. Overall color, COD, and BOD in the Stirred tank bioreactor system (STSBBR) were removed by $49.67,37.45$ and $33.89 \%$, respectively with $50 \mathrm{ppm}$ dye concentration and HRT of $24 \mathrm{~h}$. The efficiency of the reactor was found to be in negative correlation with the concentration of the dye. This STSBBR system was found very effective for efficient biological treatment of such dyeing industry waste water by the bacterial strain Pseudomonas sp.
\end{abstract}

Key Words: Pseudomonas, COD, Orange 3R, Stirred tank bioreactor, enzymatic process.

\section{INTRODUCTION}

Presently, in Bangladesh, thousands of textile units are releasing their wastes into water cadavers, exclusive of any effective waste water treatment. Though the physical and chemical methods for treatments of dyes are discouraged due to high cost, inefficiency and chemical pollution but biological treatment is safe and cost effective way for control of pollution and can be a suitable approach towards the solution of this severe issue.

Presently colored waste water from textile industry is rated as the most polluted in almost all industrial sectors in the world and has been estimated that over 10,000 different textile dyes and pigments are in common use and the total world organic colorant productions are more than 100,000 tons/year [1]. Huge amount of dyes in textile sectors are continuously being exhausted in wastewater streams due to their poor absorbability to the fiber [2,3]

Methods for treating textile dye wastewaters consist of various chemical, physical processes and Biological process $[4,5,6]$. The lower cost, no pollution of water by treating chemical and easy maintenance makes the last process more choice able then the remaining counterparts. Biological processes have potential to convert or degrade the pollutant into water, carbon dioxide and various salts of inorganic nature. The isolation of potent species and there by degradation is one of the interest in biological aspect of effluents treatment.

In this present study, the sequential stirred tank aerobic bacterial degradation system has been employed for treating Orange 3R dye containing simulated waste water, where similar system was found to be efficient in the degradation of the sulfonated azo dyes [7], for sulfur containing dyes by using white rot fungus Dichomitus squalens and Coriolus versicolor [8,9], with different pseudomonas species without shaking condition (anaerobic incubation of azo dyes) [10,11]. But most of these studies have emphasized only the decolorization/degradation of dye wastewater, not discussing much about the removal of COD \& BOD by the system. Also the isolation of the bacterial strain (Pseudomonas sp. ) was done from municipal solid waste (MSW) sample, collected from local dumping site at Rickabi-bazar point of Sylhet district which extrapolates a systematic recycling and management system for local MSW.

Thus, the main objective of this study was to isolate pseudomonas sp. from a local source and to observe 
microbial decolorization and biodegradation of Orange 3R, benzidine-based azo dye by Pseudomonas sp. in lab scale stirred tank batch bio reactor (STSBBR) and to analyze the process with respect to Color, COD \& BOD removal.

\section{MATERIALS AND METHODS:}

\subsection{Chemicals:}

The all chemicals and media component used in this study were collected from Merck (Germany). The azo dye used in this study was orange 3R (Figure 1), which was obtained from a local yarn dying industry and a Simulated textile effluent (STE) was made by adding different components as Acetic Acid (99.9\%) 0.05 $\mathrm{mL} / \mathrm{L}, \quad(\mathrm{NH} 2)_{2} \mathrm{CO} 55.00 \mathrm{mg} / \mathrm{L}, \mathrm{KH}_{2} \mathrm{PO}_{4} 34.00 \mathrm{mg} / \mathrm{L}$, $\mathrm{NaHCO}_{3} 420.00 \mathrm{mg} / \mathrm{L}$ and glucose $900.00 \mathrm{mg} / \mathrm{L}$.

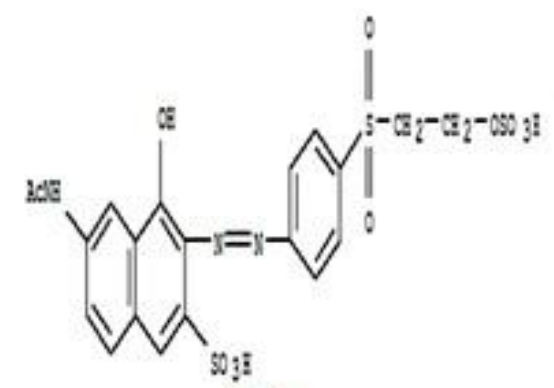

(b)

Fig 1: Orange 3R dye used for degradation ; (b)chemical structure.

\subsection{Isolation, screening and identification of dye degrading bacteria:}

\section{Selection and identification of fungi:}

The bacterial strain (pseudomonas sp.) was isolated in the Research Laboratory of Shahjalal University of Science \& Technology, Sylhet, Bangladesh which was able to biodegradation and decolorization of dyes. The source for the strain was the local waste dumping site at Rickabibazar point of Sylhet district. It was identified on the basis of the standard procedure as by Cappucino JG, Sherman N. [12].

\section{Inoculum preparation:}

Spore suspension of bacterial cultures was prepared. Bacterial cultures were refreshed on Nutrient Agar (Merck), in culture bottles. Bacteria were grown in Nutrient Agar and a loop full of bacterial culture was added into the production medium $\left(\mathrm{KH}_{2} \mathrm{PO}_{4}: 1 \mathrm{gm} / \mathrm{L}\right.$, $\mathrm{K}_{2} \mathrm{HPO}_{4}: 1.145 \mathrm{gm} / \mathrm{L}, \mathrm{MgSO}_{4}: 0.4 \mathrm{gm} / \mathrm{L}_{2} \mathrm{NH}_{4} \mathrm{SO}_{4}: 5.00$ $\mathrm{gm} / \mathrm{L}, \mathrm{CaCl}_{2}: 0.05 \mathrm{gm} / \mathrm{L}, F e S O_{4}: 0.00125 \mathrm{gm} / \mathrm{L}$ and $\mathrm{CMC}$ : $10 \mathrm{gm} / \mathrm{L}$ ) which was sterilized by autoclaving at $121^{\circ} \mathrm{C}$ for 15 minutes and then $5 \mathrm{ml}$ of production media was transferred into screw cap test tube and treated in shaker incubator at $37^{\circ} \mathrm{C}$ for 24 hours at $100 \mathrm{rpm}$ and then each of this $5 \mathrm{ml}$ medium was transferred in 4 conical flasks (with $20 \mathrm{ml}$ production media in each) and sterilized by autoclaving at $121^{\circ} \mathrm{C}$ for 15 minutes and incubated in shaker incubator at $37^{\circ} \mathrm{C}$ for 24 hours at $100 \mathrm{rpm}$.

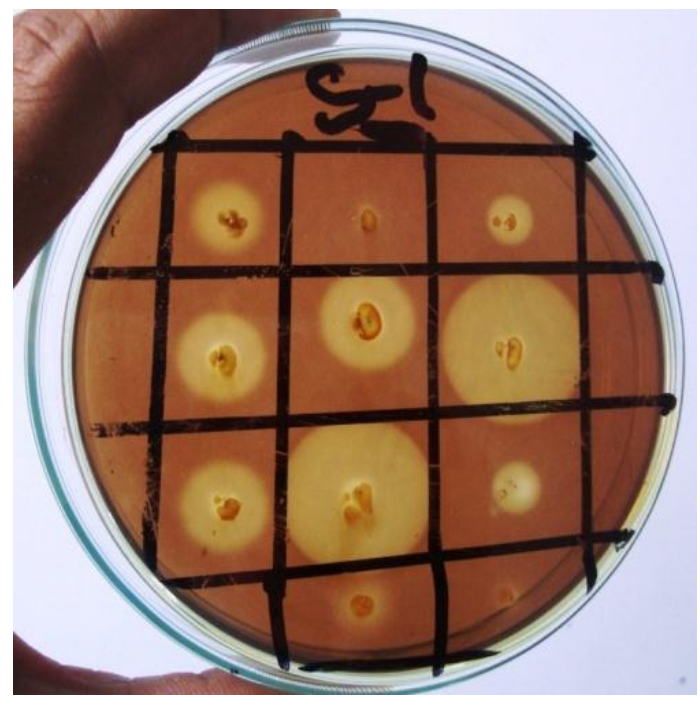

Fig 2: The bacterial colony at gram iodine staining medium.

\subsection{Operation in Stirred Tank Sequencing Batch Bioreactor (STSBBR):}

The simple lab scale stirred tank bioreactor was constructed by locally available materials. A polymeric jar of $2 \mathrm{~L}$ capacity equipped with rotor, speed controller $\&$ inlet-outlet port was used as main reactor tank.

The charging and maintaining of waste water in reactor was done by inlet-outlet port driven via the peristaltic pump (figure: 3 ). The whole operation was carried out at room temperature and ph of $\mathbf{6 . 6} \pm \mathbf{1}$ in continuous flow mode. The bioreactor was filled with 5\%-7\% spore suspension as inoculum, basal salt medium with dye concentration of $50 \mathrm{mg} \mathrm{L}^{-1}$ where hydraulic retention time was maintained as $24-72 \mathrm{~h}$ depending upon the conc. of dye in the feed. The reactor was operated with fill, react, settle and draw mode (figure: 4) while effluent was drained after 12-76 hours retention time and the reactors were charged again with the advanced concentration of dye $(100,125,150,200,300 \mathrm{ppm})$ each time. The reactor was turned to the batch mode after complete adaptation of the dye by the bacteria was achieved. Then the reactor was fed with higher dye concentrated water and the operated until the maximum decolourization is obtained.

After each batch, samples were analyzed after filtering though whatman paper no. 1 and centrifuging at 5000 rpm for 20 minutes. 


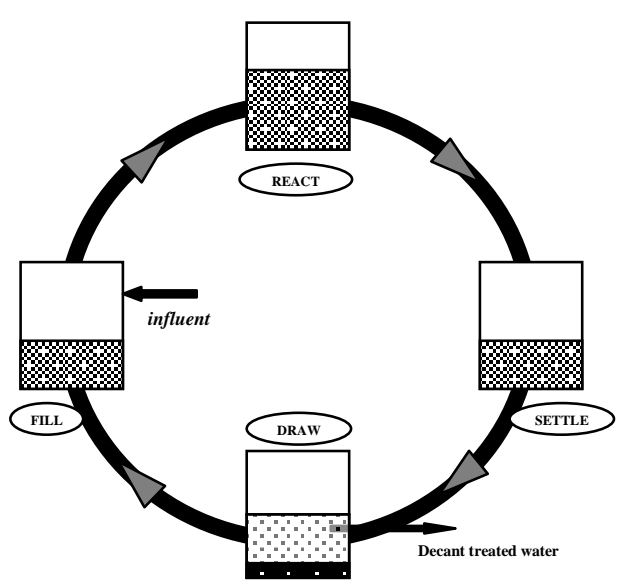

Fig 3: Schematic representation of mode of operation in STSBBR

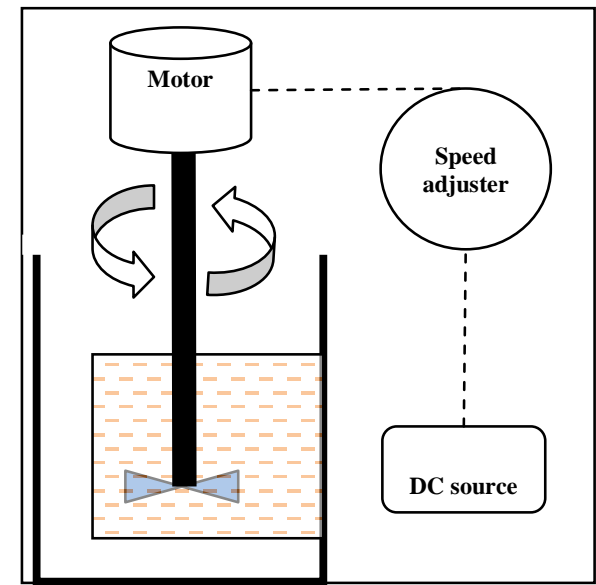

Fig 4: Configuration of the lab scale STSBBR.

\subsection{Measurement of dye concentration:}

The concentration of orange $3 R$ in samples was determined by measuring the absorbance of the supernatant of the sample at $421.00 \mathrm{~nm}$ by comparing the results, to those of the respective controls in a UVVIS spectrophotometer (SHIMANJU, model V-1650pc) after filtering though whatman paper no. 1 and centrifuging at 5,000 rpm for 20 minutes .

The percentage of decolourization was calculated by the following equation:

percent decolorization $(\%)=\frac{C_{r}-C_{t}}{C_{t}} \times 100 . .(1$

Where, $C_{r}$ and $C_{t}$ are the concentration of the dye in raw and treated solutions, respectively.

\subsection{Chemical Oxygen Demand (COD) measurement:}

The COD was measured by titrimetric method. The COD was calculated by following equation:

$$
\mathrm{COD}\left(\mathrm{mg} \mathrm{O}_{2} / \mathrm{L}\right)=\frac{(b-s) M}{8000} \times \text { dilution factor .. }
$$

Where, b, s, M are ml FAS used for blanks, ml FAS used for sample, molarity of FAS respectively.

\subsection{Biological oxygen demand (BOD):}

BOD analysis of waste water before and after treatment carried out by using 5-Day BOD Test (APHA standard method).

\section{RESULT}

Color removal: Greatest color removal was observed as of $84.53 \%$, when the reactor was operated for 14 hours (HRT 14h) with $50 \mathrm{ppm}$ Orange 3R dye in the Stirred Tank Sequencing Batch Bioreactor (STSBBR). The rate of color removal was found to be in opposite correspondence with the dye loading rate of the reactor as demonstrated by Figure: 6. So, from here, we can assume that increasing the concentration of dye in the input feed of the reactor leads the decrement of the dye removal performance of the reactor. In this study, 49.67, $47.85,35.47,5.08$ and $2.20 \%$ dye was removed during the treatment of 100,150,200, 250 and $300 \mathrm{ppm}$ dye in the bio-reactor with operational HRT in the range of 24h-72h.

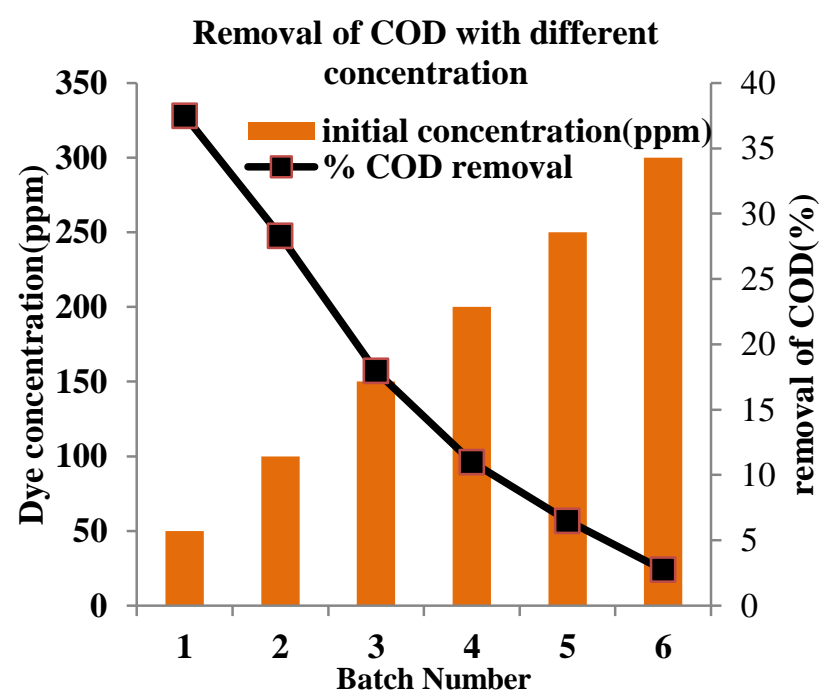

Fig 5: COD removal by STSBBR operation with different dye loading.

COD removal: The similar fashion of decreasing of reactor performance was found for removal of COD levels where increasing COD load to reactor during operation found to lowers the ultimate removal of COD. A maximum COD removal of $37.45 \%$ was obtained at low influent dye concentration of $50 \mathrm{ppm}$. The reduction level was major up to $150 \mathrm{ppm}$ dye treatment. For further increment of COD load to the reactor caused the poor COD reduction $(26.07 \%, 18.38 \%, 10.20 \%$ \& $44.15 \%$ ), indicating that COD removal of STSBBR is alternating by dye COD (Figure: 5). 


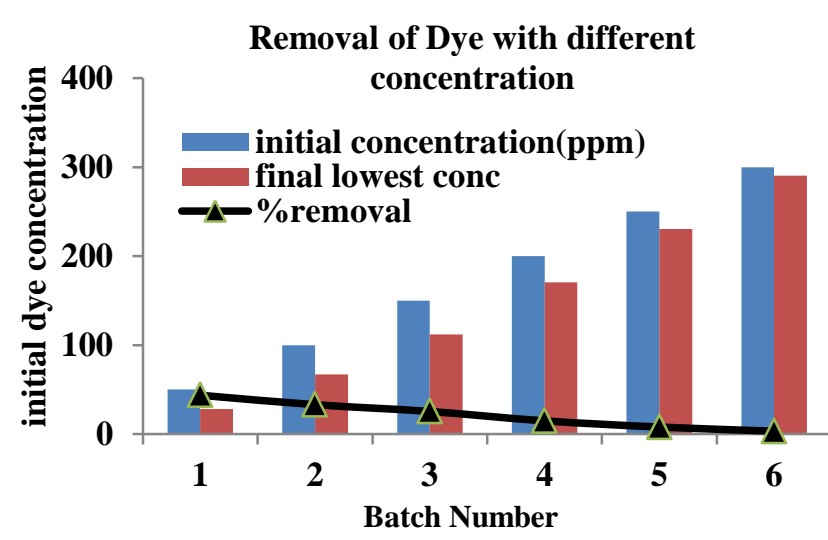

Fig 6: Removal of Dye with different concentration in STSBBR.

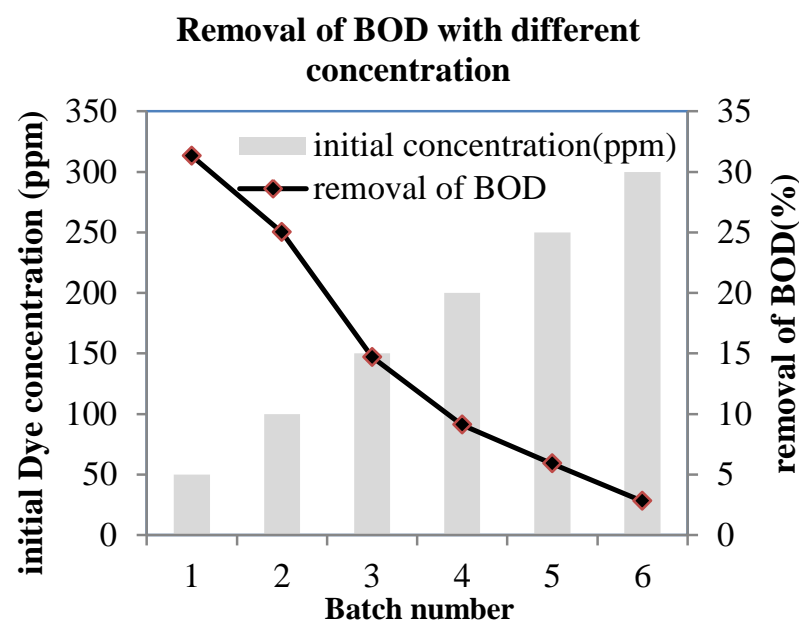

Fig 7: Removal of BOD with different concentration in STSBBR.

BOD removal: The rate of $B O D$ removal was found to be lessening with increasing dye concentration in the whole experimental limit (50 ppm - $300 \mathrm{ppm}$ dye in feed). Within this limit of dye concentration feed to the reactor input, BOD removal again followed the same trend as by colour \& COD i.e., higher the dye loading rate, lower the removal efficiency. Maximum BOD was reduced at $72 \mathrm{~h}$ HRT (33.89\%), with considerable decline up to $150 \mathrm{ppm}$ dye feeding to STSBBR (Figure: 7).

\section{DISCUSSION}

Stirred tank sequencing batch bioreactor (STSBBR) treatment approach was implied for biological exclusion of Orange 3R dye from simulated textile effluent effectively by bacterial strain pseudomonas sp.. Pseudomonas is a Gram-negative, aerobic, rod shaped bacterium with optimum temperature for growth is $37^{\circ} \mathrm{C}$ degrees, and it is able to grow at temperatures as high as $42^{\circ} \mathrm{C}$ degrees. The isolation was done from municipal solid waste and showed higher decolorization and identified as pseudomonas $s p$ and this newly isolated indigenous bacterium Pseudomonas sp. was able to degrade this simulated textile waste water in lab scale bio-reactor.

In a study of decolorization of sulfur black dye by a bacterial strain (Aspergillus terreus SA3), the similar decolorization pattern has reported by Saadia Andleeb, Naima Atiq, Muhammad Ishtiaq Ali (1996)[13] Efficiency of that bacterial strain increased to a maximum (about $85 \%$ ) when the concentration of sulfur black was $50 \mathrm{ppm}$ but dropped rapidly as the concentration rose stepwise to 500. Increased retention time enabled the bacterial system to adjust the sudden increase of dye loading rate and helps the system to manage with chemical shock. The consequence of hydraulic retention time (HRT) on the removal efficiencies Orange II and COD was analysed in a study. It was concluded that the COD and Orange II removal efficiencies were enhanced from 27 to $35 \%$ and 82 to $97 \%$, respectively by the increase of HRT from 24 to $48 \mathrm{~h}$ [14]. Pourbabaee et al. (2006)[15] also found similar lessening in BOD and COD while studying a aerobic decolorization and detoxification of a disperse dye (Terasil Black) Bacillus sp. These reductions in BOD and COD level are the indication of the formation of new metabolites during the time of biological decolourization process which may contribute to the total COD and BOD freights, thus decreasing ability of dye removals.

\section{CONCLUSION:}

This paper represents an inexpensive, readily available and suitable management with reuse of waste biomass that has a noteworthy potential for textile effluent treatment and thus is an important and capable approach for the removal of dye from textile effluent and waste management. The cost effectiveness and easy maintenance of this system makes it highly acceptable for biological treatment of textile waste in developing countries like Bangladesh to provide a better environment for upcoming generation.

\section{REFERENCES:}

[1]Easton, J.R., 1995. The dye maker's view. In: Cooper, P. (ed.), Colour in Dyehouse Effluent, pp: 9-21. Society of Dyehouse and Color,Bradford, England.

[2]Robinson T., McMullan G., Marchant R. and Nigam P. (2001) "Remediation of dyes in textile effluent: a critical review on current treatment technologies with a proposal alternative" Bioresource Technology 77: 247-255.

[3]Wagner, S., 1993. Improvement in Products and Processing to Diminish Environmental Impact. COTTECH Conference, Raleigh NC. 
[4]Bilal A., Journal of Colloid and Interface Science, 2004, 274, 371-379.

[5]Chakraborty S. ,Purkait M.K. ,DasGupta S. ,De S. ,Basu J.K. ,Separation and Purification Technology ,2003,31, 141-151.

[5]Roy D., Valsaraj K.T. and Kottai S.A., Separation Sci. Technol., 1992, 27, 573-88.

[6]Liu, R.L.H., H.-M. Chiu and R.Y.L. Yeh, 2003. Intl. J. Environ. Studies, 59: 143-158.

[7]Rajaguru, P., Kalaiselvi, M., Palanivel, M., Subburam, V., 2000. Biodegradation of azo dyes in a sequential anaerobic-aerobic system. Appl. Microbiol. Biotechnol. 54, 268-273.

[8]Eichlerova', I., Homolka, L., Nerud, F., 2006. Synthetic dye decolorization capacity of white rot fungus Dichomitus squalens. Bioresour. Technol. 97, 2153-2159.

[9]Sanghi, R., Dixit, A., Guha, S., 2006. Sequential batch culture studies for the decolorization of reactive dye by Coriolus versicolor. Bioresour. Technol. 97, 396-400.

[10]Banat, I.M., Nigam, P., Singh, D., Marchant, R., 1996. Microbial decolorization of textile-dye containing effluents: a review. Bioresour. Technol. 58, 217-227.

[11]Puvaneshwari, N., Muthukrishnan, J., Gunasekaran, P., 2002. Biodegradation of benzidine based azodyes direct red and direct blue by the immobilized cells of Pseudomonas fluorescens D41. Indian J. Exp. Biol. 40, 1131-1136

[12]Cappucino JG, Sherman N. (1987). Microbiology a Laboratory Manual. 2th Ed. California: The Benjamins Columning Publ Company.

[13] Saadia Andleeb, Naima Atiq, Muhammad Ishtiaq Ali ,Biological Treatment of Textile Effluent in Stirred Tank Bioreactor, International Journal of Agriculture \& Biology, 1996.

[14]Ong, S.A., E. Toorisaka, M. Hirata and T. Hano, 2005. Treatment of azo dye Orange II in aerobic and anaerobic-SBR systems. Process Biochem., 40: 2907-2914.

[15]Pourbabaee, A.A., F. Malekzadeh, M.N. Sarbolouki and F. Najafi, 2006. Aerobic Decolorization and Detoxification of a Disperse Dye in Textile Effluent by a New Isolate of Bacillus sp. Wiley Inter Science. (www.interscience.wiley.com), DOI: $10.1002 /$ bit.20732 